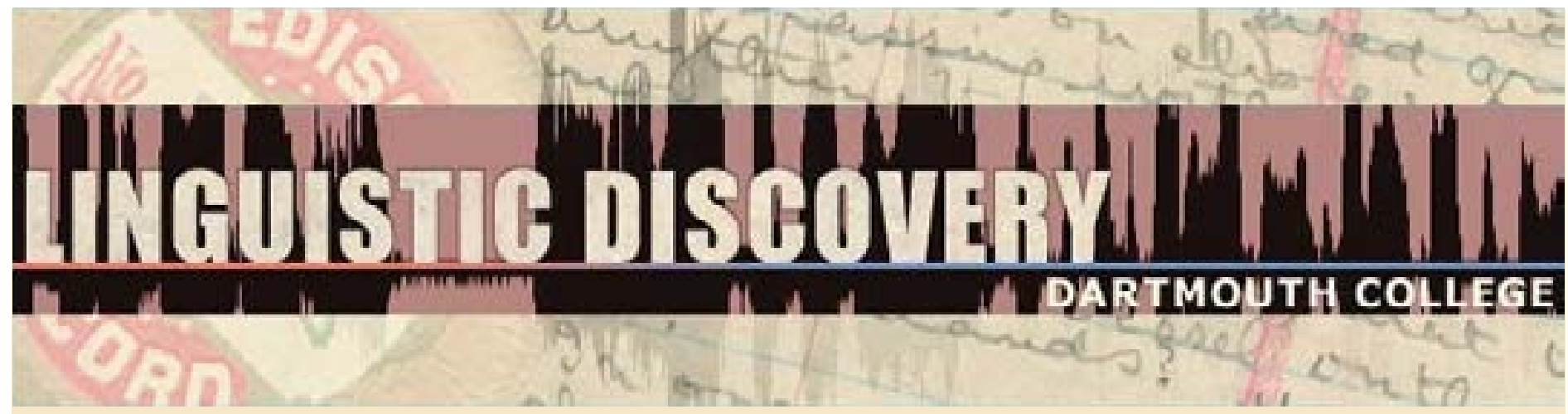

Volume 6 Issue 1 2008
Stress, Extrametricality and the Minimal Word in Seri

Stephen A. Marlett

SIL International and University of North Dakota

doi: 10.1349/PS1.1537-0852.A.321

url: http://journals.dartmouth.edu/cgi-bin/WebObjects/ Journals.woa/1/xmlpage/1/article/321 


\title{
Stress, Extrametricality and the Minimal Word in Seri
}

\author{
Stephen A. Marlett \\ SIL International and University of North Dakota
}

Seri, a language isolate spoken in northwestern Mexico, regularly assigns stress to the penultimate syllable of a root; affixes are not relevant for determining the placement of stress. A heavy final syllable in the root attracts stress, however, although a final consonant is extrametrical. The final consonant of a word is relevant for the minimal word condition that major class lexical items respect, as this paper shows. Some roots have extrametrical final syllables and a few roots have exceptional stress. This paper documents these facts with audio recordings.

\section{Introduction}

This paper presents an analysis of Seri stress. ${ }^{1}$ It shows that stress placement crucially refers to morphological information (the end of the root) and syllable weight. The final consonant of the root is extrametrical; a moraic trochee is constructed at the right edge of the root and is limited to the root. The analysis given here allows the inclusion of Seri into modern typologies of stress systems.

\section{Previous analyses}

The first work mentioning stress in Seri is Kroeber's (1931: 31) statement that the language has "marked tone instead of stress accent," and that the "tone variations are great enough to be unusually plain." This impression was the result of a few days of fieldwork oriented mainly toward collecting anthropological and comparative linguistic information that was published as a monograph. The next mention of stress is found in the published report of a prolonged study that finds no evidence for tone, Moser and Moser (1965), in which the authors say that stress is phonemic and can distinguish between words (p. 56). The report gives the examples in (1), and I have included in (2) another (non-minimal) pair that parallels their examples. ${ }^{2}$

\footnotetext{
${ }^{1}$ Seri (ISO 639-3 sei) is a linguistic isolate spoken in northwestern Mexico that has been considered part of the controversial Hokan family. For more basic information about this language, see Marlett (2005); for information regarding the genetic relationship, see Campbell (1997) and Marlett (2008). I thank Andy Black, Megan Crowhurst, Larry Hagberg, Cathy Marlett, Maggie Romani, Steve Parker and anonymous reviewers for their comments on earlier drafts of this paper, which is an expansion of Marlett (2006a). Parts of it were presented at the 2007 annual meeting of the Society for the Study of Indigenous Languages of the Americas in Anaheim. Some of the work on this study was facilitated by an NEH fellowship from the program for documenting endangered languages (FN50007-06). The WAV recordings of the data were made by the author in Punta Chueca, Sonora, of René Montaño Herrera (whose cooperation is gratefully acknowledged), in the spring and summer of 2007 on an Edirol R-09 recorder with a headset microphone, at a sampling rate of $44.1 \mathrm{kHz}$. Almost all of the data in this paper are found in Moser and Marlett (2005).

${ }^{2}$ All of the examples are cited in the alphabet used in the recent dictionary (Moser y Marlett 2005). A basic guide to the phonetic values: $a[\mathrm{a}]$, aa $[\mathrm{a}]], c[\mathrm{k}], c \ddot{o}\left[\mathrm{k}^{\mathrm{w}}\right]$, e $[\varepsilon]$, ee $[\varepsilon \mathrm{z}], f[\phi], h[?], i[\mathrm{i}], i i[\mathrm{i}], j[\mathrm{x}], j \ddot{0}\left[\mathrm{x}^{\mathrm{w}}\right], l[\mathrm{f}], \underline{l}[1], m$ $[\mathrm{m}]$ (but $[\mathrm{y}]$ in some contexts), $n[\mathrm{n}], o[\mathrm{o}], o o[\mathrm{o}], p[\mathrm{p}], q u[\mathrm{k}], r[\mathrm{r}], s[\mathrm{~s}], t[\mathrm{t}], x[\chi], x \ddot{o}\left[\chi^{\mathrm{w}}\right], y[\mathrm{j}], z\left[\int\right]$. The obstruent stops are: $p, t, c / q u, c \ddot{o}$. Obstruent fricatives are $f, l, s, z, j, j o ̈, x, x o ̈$. The sonorant consonants are: nasals $m$, $n$. (rare) lateral $1, y, h$ (glottal stop, which indeed patterns with the sonorants), and $r$ (from loanwords). The vowels pattern as low $(a, e)$ and non-low $(i, o)$; all occur both short and long. See Marlett, Moreno Herrera and
} 
(1a) hípxaz /'Pipxas/ 'my nephew (of woman)'

(1b) hipxáz /Ri'pxas/ 'our flesh'

(2a) ímac /'imak/ 'its middle'

(2b) amác /a'mak/ 'his/her sponsor' (in Seri culture)

In previous work of my own (Marlett 1981) I have attempted to explain that examples such as these may be analyzed with a simple rule, given here as (3):

(3) Stress falls on the first syllable of the root.

In the case of 'nephew (of woman)', the root begins with an empty vowel which is stressed and then fuses with the vowel of the prefix $h i$-. In the case of 'our flesh', the root is ${ } p x a z$, , and for that reason stress falls on the vowel $a$ in that word. This analysis is shown in (4) and it applies mutatis mutandi to the examples in (2).

$$
\begin{array}{lll}
\mathrm{hi}+\mathrm{Vpxaz} & \rightarrow & \mathrm{hi}+{ }^{\prime} \mathrm{Vpxaz} \\
\mathrm{hi}+\mathrm{pxaz} & \rightarrow & \mathrm{hi}+\mathrm{pxáz}
\end{array}
$$$$
\rightarrow \quad \text { hípxaz 'my nephew (of woman)' }
$$$$
\rightarrow \text { hipxáz 'our flesh' }
$$

This analysis has a slight amount of abstraction in that the empty vowel (which may be long or short) always fuses with a prefix vowel; therefore the root has that degree of underspecification. A similar pattern occurs with verb roots, but in the case of verbs one can see a fully-specified underlying vowel at times because there are consonant-final prefixes which occur with verbs, as in $(5 \mathrm{a}, \mathrm{b}, \mathrm{d}, \mathrm{f})$. Verbs also maintain each mora of the prefix and root-initial vowel, resulting in long vowels, unlike the nouns; see examples $(5 \mathrm{c}, \mathrm{e})$.
(5a) $\mathrm{t}+\mathrm{asa}$
(5b) $\mathrm{t}+\mathrm{m}+\mathrm{asa}$
$\rightarrow$ tása
/'tasa/
$\rightarrow$ tmása
/'tmasa/
$\rightarrow$ síisa
/'sissa/
/'smasa/
'it stinks' (dependent realis)
(5c) $\mathrm{si}+$ asa
(5d) $\mathrm{si}+\mathrm{m}+\mathrm{asa}$
'it doesn't stink' (negative dependent realis)
$\rightarrow$ smása
'it will stink' (independent irrealis)
(5e) po + asa
$\rightarrow$ póosa /'po:sa/
'it will not stink' (negative independent irrealis)
(5f) po $+\mathrm{m}+$ asa
$\rightarrow$ pomása
/po'masa/
'it will stink' (dependent irrealis)
'it will not stink' (negative dependent irrealis)

Independent motivation for this analysis is found with the allomorphy for the 'absolutive' (unpossessed) prefix which occurs with kinship terms: the prefix is $h a$ - before consonant-initial roots (as in (6a-d), and hape- before vowel-initial roots (those with V or VV), as in (6e-i). ${ }^{4}$ Some of the stem vowels also harmonize with the $e$ of the prefix hape-.

\footnotetext{
Herrera Astorga (2005) for more details about the allophonic details. In this paper stress is indicated on all stressed words, unlike the orthography generally (where written accent is hardly written at all — see Marlett 2006b) and unlike the 2005 dictionary (where it is written following certain conventions as part of the historical record). Cathy Marlett updated the glosses of a few words based on her forthcoming monograph on the ethnography of mollusks. Two words were corrected from the spelling in the dictionary: héezitim (38k) replacing hézitim and xpasiiticl (43h) replacing xpasiticl. The IPA transcriptions indicate stress with a raised vertical stroke before the prominent syllable; syllabification maximizes the onset of the stressed syllable, as argued to be appropriate in Marlett (1988:268).

${ }^{3}$ I use the radical symbol $\sqrt{ }$ to indicate the beginning of a bound inflectional root.

${ }^{4}$ This generalization is almost exceptionless.
} 


\begin{tabular}{|c|c|c|c|c|}
\hline$(6 a)$ & $\begin{array}{l}\text { Root } \\
\sqrt{\text { paac }}\end{array}$ & $\begin{array}{l}\text { Absolutive } \\
\text { hapáac }\end{array}$ & /2a'pa:k/ & 'older sister (of male)' \\
\hline 6b) & $\sqrt{m a h a j}$ & hamáhaj & /Ra'maiax/ & 'father's older brother' \\
\hline c) & $\sqrt{\text { camaz }}$ & hacámaz & /Ra'kamaS/ & 'daughter-in-law' \\
\hline d) & $\sqrt{c a a c}$ & hacáac & /Ra'ka:k/ & 'daughter (of female)'s child' \\
\hline e) & $\sqrt{V V c a z}$ & hapéequez & /Ra'pe:kef/ & 'younger brother (of female)' \\
\hline f) & $\sqrt{ }$ Vpaz & hapépez & /Ra'pepeS/ & 'father's father' \\
\hline$g$ & $\sqrt{ }$ ta & hapéte & /Ra'pete/ & 'mother' \\
\hline & $\sqrt{ } \mathrm{VVz}$ & hapéez & /Ra'pe:S/ & 'mother's father' \\
\hline & $\sqrt{ }$ VVitz & hapéetz & /2a'pe:t $\int /$ & 'father's younger brother' \\
\hline
\end{tabular}

This analysis shows that although stress is "phonemic" in the sense that it may distinguish different utterances, it is not "phonemic" in the sense of being "not predictable," because if one knows something about the morphology of the language, stress can be correctly placed on the word, at least in these and many similar examples. ${ }^{5}$ Since structuralist phonology did not permit access to morphological information, this solution was not possible for analyses of that era.

Nevertheless, this formulation of the rule — "Stress falls on the first syllable of the root"has many exceptions. In the past I have attributed these exceptions to the fact that they are compounds or that they have reanalyzed some affix to be part of a new root (see Marlett (2002) for examples of this type of reanalysis), and I still believe that is true for many of them, but not for all. The analysis presented below greatly reduces the number of exceptions.

\section{Phonetics of stress}

Stress is most commonly realized in Seri as a higher pitch on the stressed syllable. In a certain kind of construction used to express disbelief, the stressed syllable is pronounced with a rather low pitch, however, as in (7).

$\begin{array}{rll}\text { ¡¿Śimet } & \text { a } & (-y a) ? ! \\ \text { bread } & \text { Auxiliary } & \text { Interrogative }\end{array}$

Stress also has a notable effect on the consonants and vowels after the stressed vowel as shown in (8) and (9), causing either moderate lengthening (as indicated by the IPA symbol [']) or more noticeable lengthening (as indicated by the IPA symbol [:]).

\footnotetext{
${ }^{5}$ There will still be challenges as one also needs to know what words belong to major categories (nouns, verbs and the rare adjective - almost always stressed) and to minor categories (adverbs, postpositions, determiners sometimes stressed or not stressed at all). One also needs to know how phrases are stressed, including verb phrases. Entire clauses may have reduced stress as well. These challenges are not discussed in this paper.
} 
(8a) A non-suffixal consonant following a stressed vowel is lengthened. The lengthening is moderate if the stressed nucleus is bimoraic, as in (9b), and more noticeable if the stressed nucleus is monomoraic, as in (9a). Contrast these with (9c-d), which have suffixal consonants (which do not lengthen).

(8b) A non-suffixal vowel following such a consonant is lengthened as well — slightly more after a short stressed nucleus than after a long stressed nucleus. Contrast (9a-b) with $(9 \mathrm{c}-\mathrm{d})$.

(8c) A stressed long vowel is slightly shorter when it appears before a lengthened consonant than elsewhere; see (9b). ${ }^{6}$

(9a) hápaj ['Rapra:x] 'octopus'

(9b) cóotaj ['ko't'a'x] 'ant'

(9c) cóo-taj ['ko:tax] 'guitarfish (pl.)'

(9d) i-t-cáa-tim [i'tka:tim] 's/he looked for her/him/it/them repeatedly' (3:3-Realislook.for-Imperfective)

These phonetic facts have been documented elsewhere (Moser and Moser 1965, Marlett 1981, Marlett, Moreno Herrera and Herrera Astorga 2005) and are given here only as background information for the discussion on stress placement.

Phrases and compounds retain the stress of the rightmost element as shown in (10). ${ }^{7}$ Vowel length on other formatives is greatly reduced, if not entirely neutralized, in compounds. This seems to correlate with the fact that in monomorphemic words (as well as almost all compounds) contrastive long vowels and even diphthongs co-occur with stress. Long vowels do not occur contrastively in unstressed syllables.

(10a) zíix cóla hapáh phrase: 'thing that is put up high’; primary stress on hapáh thing high put

(10b) ziix cola hapáh analytic compound: 'flag'; primary stress on hapáh and slight

(10c) zixcolahapáh reduction of length on ziix synthetic compound: 'kite'

Stress on the verb phrase leads to some interesting contrasts. The so-called postpositions must occur in preverbal position and have reduced stress if their complement is overt. If their complement is not overt, they are more likely to have more prominent stress. This leads to the type of contrast shown in (11-12) - superficially contrastive stress that is entirely predictable based on the syntactic structures of the examples.

\footnotetext{
${ }^{6}$ This shortening makes vowel length difficult to perceive in such words until one makes direct comparison with words containing short vowels. The two major patterns of $/ \ldots{ }^{\prime} \mathrm{VCV} /$ and $/ \ldots{ }^{\prime} \mathrm{V}: \mathrm{CV} /$ monomorphemic words are therefore, respectively, [' $\mathrm{VC}: \mathrm{V}:$ ] SLL (short, lengthened, lengthened) and [ $\left.{ }^{\prime} \mathrm{V}^{\cdot} \mathrm{C}^{\cdot} \mathrm{V}^{\prime}\right] \mathrm{MMM}$ (moderate-long, moderate-lengthened, moderate-lengthened). The contrast between short and long vowels is clear, but one has to be tuned in to the phonetic cues in order to perceive them correctly.

${ }^{7}$ I have difficulty perceiving the difference between (10b) and (10c), as do some Seri speakers. Others insist on the difference between all three expressions, which were first contrasted in Marlett, Moreno Herrera and Herrera Astorga (2005).
} 
(11)

Quíiquet quih ìiqui yopánzx.

his/her mother the toward s/he ran

'S/he ran toward his/her mother.'
Quíiquet
quih
yopánzx.
his/her mother the toward s/he ran
'His/her mother ran toward him/her.'

\section{Word structure and syllable structure}

Before we look at the placement of stress on words, I present a few basic facts about the form of words. First, Seri is a mildly polysynthetic language. The most productive affixes are prefixes. Suffixes are relatively few and primarily indicators of plurality (whether on the noun or on the verb) and many of these are irregular. I include here only a few simple inflected words to illustrate:
a-záac-la /a' /a:kła/
3Possessor-older.sister-Plural
a-cámal-coj /a'kamałkox/
3Possessor-daughter.in.law-Plural ${ }^{8}$
(15)
ha-yo-m-áh-t /Rajo'ma?t/
1Plural.Subject-Distal-Negative-see-Plural ${ }^{9}$
ha-yo-m-áh-tolca /Rajo'ma?tołka/
'her older sisters'
'their daughter(s)-in-law'
'we didn't see him/her/it/them'
1Plural.Subject-Distal-Negative-see-Plural/Imperfective

Syllables can be complicated. I have proposed elsewhere (Marlett 1988) that the maximal syllable may begin with two consonants and end with three, that the onset is obligatory (except in word-initial position, as in many other languages) and that there is word-initial consonant extrametricality at the beginning of the word (especially with affixes). The nucleus commonly contains more than one vowel and commonly has up to three moras. ${ }^{10}$ Examples appear later in this paper (see (19a), (31e), (34e), among others).

A Seri word requires at least two moras if it is a noun or verb. ${ }^{11}$ Vowels and coda consonants count as moraic for this generalization. A long vowel counts as two moras as do diphthongs of

\footnotetext{
${ }^{8}$ The singular form is acámaz. The plural form given here explicitly indicates plurality of possessor and leaves the number of the possessed item vague.

${ }^{9}$ The singular stems for 'see' are $\sqrt{ }$ aho (perfective) and Vaho-tim (imperfective); Vaho is arguably the root of the verb. The plural stems (in this case) are formed by dropping the vowel of the second syllable and adding the suffixes.

${ }^{10}$ A syllable with a stressed long vowel only has stress on the entire vowel. If the nucleus has a bimoraic diphthong $a i, o i, e i, a o$ or $e a$, stress is perceived as falling on the first vowel; but if has a bimoraic diphthong oe or $o a$, stress tends to be perceived on the second vowel. If the nucleus is trimoraic, combining a long vowel and a short vowel (both orders possible), the facts are less straightforward phonetically; the locus of stress depends on the vowel quality, the vowel length, and even the speaker. These details are not laid out here.

${ }^{11}$ This claim appears for the first time in Marlett (2006a). Adjectives are an extremely small class in the language, but they also adhere to the two-mora requirement, as do adverbs.
} 
two vowels. ${ }^{12}$ As a result, words such as those in (17) do not exist except as special words of other classes. (Those without an accent here are clearly unstressed in all contexts and cliticize phonetically to an adjacent word.)

$\begin{array}{llll}(17 \mathrm{a}) & \text { hé } & / \mathrm{T} \varepsilon / & \text { First person independent pronoun } \\ (17 \mathrm{~b}) & \mathrm{mé} & / \mathrm{me} / & \text { Second person independent pronoun } \\ (17 \mathrm{c}) & \text { ta } & / \mathrm{ta} / & \text { Different Subject in Irrealis clauses } \\ (17 \mathrm{~d}) & \mathrm{ma} & / \mathrm{ma} / & \text { Different Subject in Realis clauses } \\ (17 \mathrm{e}) & \mathrm{pti} & / \mathrm{pti} / & \text { 'together, Reciprocal' } \\ (17 \mathrm{f}) & \mathrm{ca} & / \mathrm{ka} / & \text { Auxiliary } \\ (17 \mathrm{~g}) & \text { ta } & / \mathrm{ta} / & \text { Auxiliary } \\ (17 \mathrm{~h}) & \text { xó } & / / \chi \mathrm{l} / & \text { 'but' } \\ (17 \mathrm{i}) & \text { zo } & / \mathrm{So} / & \text { 'a, an' (indefinite article) } \\ (17 \mathrm{j}) & \text { zó } & / \mathrm{Jo} / & \text { 'how?' }\end{array}$

On the other hand, the words in (18) are ordinary nouns with an occasional adverb or adjective. Each one has two moras; those in (18) by having two syllables, those in (19) by having a long vowel or diphthong, and those in $(20)$ by having a consonant in the coda. ${ }^{13}$

Two syllable words

\begin{tabular}{|c|c|c|c|}
\hline$(18 \mathrm{a})$ & cáma & /'kama/ & 'big skate (Raja binoculata)' \\
\hline$(18 b)$ & cósi & /'kosi/ & 'thorn' \\
\hline$(18 \mathrm{c})$ & cola & /'koła/ & ‘high’ \\
\hline$(18 d)$ & háso & /'Raso/ & 'net' \\
\hline$(18 \mathrm{e})$ & xépe & /' $\chi \varepsilon p \varepsilon /$ & 'sea' \\
\hline & Monosyllabic words & with two vowels & or with a long vowel \\
\hline (19a) & hái & /'Pai/ & 'wind' \\
\hline$(19 b)$ & cóo & /'ko:/ & 'guitarfish (Rhinobatos productos)' \\
\hline$(19 \mathrm{c})$ & hée & /'Pع:/ & 'antelope hare (Lepus alleni)' \\
\hline$(19 d)$ & xjíi & $/{ }^{\prime} \chi x i: /$ & 'bottle gourd (Lagenaria siceraria)' \\
\hline & Monosyllabic words & with a coda & \\
\hline (20a) & $\underline{a ́ c}$ & /'ak/ & 'canvasback (Aythya valisineria)' \\
\hline$(20 b)$ & $\underline{a ́ s}$ & /'as/ & 'sing!' \\
\hline$(20 c)$ & ám & /'am/ & 'her father' \\
\hline$(20 d)$ & $\underline{1} \underline{s}$ & /'is/ & 'its immature fruit' \\
\hline$(20 \mathrm{e})$ & cám & /'kam/ & 'a bark boring beetle' \\
\hline (20f) & cáp & /'kap/ & 'palo blanco (Acacia willardiana)' \\
\hline$(20 g)$ & cós & /'kos/ & 'a shrub (Maytenus phyllanthoides)' \\
\hline$(20 \mathrm{~h})$ & sáh & /'sa?/ & 'great horned owl (Bubo virginiana)' \\
\hline (20i) & $\underline{\text { stác }}$ & /'stak/ & 'pumice' \\
\hline
\end{tabular}

${ }^{12}$ There is no evidence anywhere, to the best of my knowledge, of any lengthening taking place to satisfy the minimal word constraint.

${ }^{13}$ For the record, the language allows words with long vowels in closed syllables. A few examples of the many which could be provided: cool /'ko:\&/ 'net bag', haan /'Ra:n/ 'smooth Pacific venus clam', haap /'Ra:p/ 'wild tepary', peen /'pe:n/ 'carrying pole', quiit /'ki:t/ 'little heart shell', xeen /' $\chi \varepsilon: n /$ 'raccoon', xоop /' $\chi 0: p /$ 'elephant tree', caanj /'ka:nx/ 'Gulf grouper', saacj/'sa:kx/ 'large horse mussel', haait /'?a:it/ 'blood', caaisX /'ka:is / 'one who cleans it', caaipj /'ka:ipx/ 'one who makes oval-shaped basket', cooipj /'ko:ipx/ 'oval-shaped', haaizj /'?a:ijx/ 'mash made of cooked cactus fruit'. 
Therefore we know that the coda - whether it is a sonorant or an obstruent - contributes a mora just the same as a second vowel or a long vowel to meet the bimoraic requirement for a minimal word in Seri.

\section{Trochaic foot}

The examples in (21)-(32) show that stress normally falls on the penultimate syllable of polysyllabic words. Since it is irrelevant whether medial consonant clusters are tautosyllabic or not, syllable boundaries are not shown. ${ }^{14}$

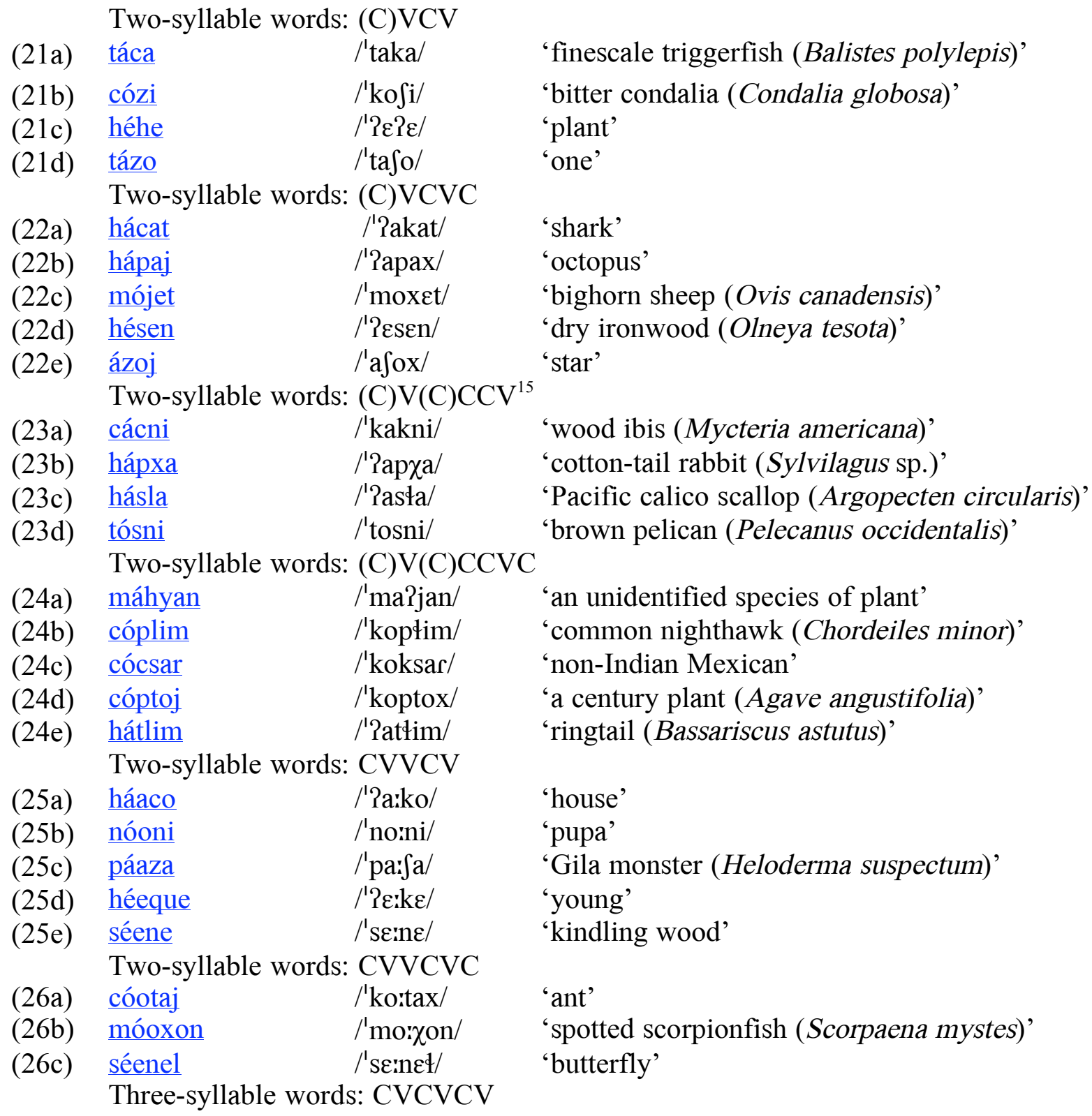

\footnotetext{
${ }^{14}$ Syllables with more complicated onsets are possible but such examples do not add to the discussion.

${ }^{15}$ The medial clusters are not all equivalent; sonorants and obstruents syllabify differently (Marlett 1988). Nevertheless, the difference is not pertinent here.
} 


\begin{tabular}{|c|c|c|c|}
\hline$(27 a)$ & comíma & /ko'mima/ & 'Coulter brickell-bush (Brickellia coulteri)' \\
\hline$(27 b)$ & moxíma & /mo'xima/ & ‘yesterday’ \\
\hline$(27 c)$ & sayána & /sa'jana/ & 'common olive (snail) (Olivella dama)' \\
\hline$(27 d)$ & mojépe & /mo'xepe/ & 'sahuaro (Carnegiea gigantea)' \\
\hline & \multicolumn{3}{|c|}{ Three-syllable words: (C)CVCVCVC } \\
\hline$(28 \mathrm{a})$ & casópaj & /ka'sopax/ & 'Panamic pearl oyster (Pinctada mazatlanica)' \\
\hline$(28 b)$ & catámax & $/ \mathrm{ka}^{\prime} \operatorname{tama} \alpha$ & 'cup-and-saucer limpet (Crucibulum scutellatum)' \\
\hline$(28 \mathrm{c})$ & comítin & /ko'mitin/ & 'green ironwood (Olneya tesota)' \\
\hline$(28 d)$ & xpasípip & 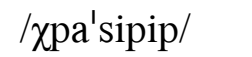 & 'dragonfly (Odonata)' \\
\hline$(28 \mathrm{e})$ & xamátaj & /xa'matax/ & 'broth' \\
\hline & \multicolumn{3}{|c|}{ Three-syllable words: CVCVCCV } \\
\hline (29a) & canócni & /ka'nokni/ & 'Heermann’s gull (Larus heermanni)' \\
\hline (29b) & tozípla & /to'sipła/ & ‘side-blotched lizard (Uta stansburiana)’ \\
\hline$(29 c)$ & hacálco & /Ra'kałko/ & 'dolls and related items that are played with' \\
\hline & \multicolumn{3}{|c|}{ Three-syllable words: CVCVCCVC } \\
\hline$(30 \mathrm{a})$ & camázjij & $/ \mathrm{ka}^{\prime} \operatorname{ma} \int \mathrm{xix} /$ & 'a venus clam (Megapitaria squalida)' \\
\hline (30b) & capóclim & /ka'poktim/ & 'chiton (Chitonidae)' \\
\hline$(30 c)$ & zacápnij & / `a'kapnix/ & 'ball of dirt or fruit' \\
\hline & \multicolumn{3}{|c|}{ Three-syllable words with a long vowel or diphthong in the penultimate syllable ${ }^{16}$} \\
\hline (31a) & contéetxyat & 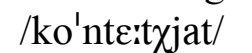 & 'stinkbug (Eleodes spp.)' \\
\hline$(31 b)$ & comáanal & /ko'ma:nat/ & 'yerba mansa (Anemopsis californica)' \\
\hline$(31 \mathrm{c})$ & conzéezla & /kon'se:fta/ & 'a small unidentified ant' \\
\hline$(31 d)$ & jomxéeziz ${ }^{17}$ & /xom $\chi \varepsilon: \int i \int /$ & 'ocotillo (Fouquieria splendens)' \\
\hline$(31 \mathrm{e})$ & camáaina & /ka'maina/ & 'an unidentified manta ray' \\
\hline (31f) & catíiija & /ka'ti:ixa/ & 'common loon in winter plumage (Gavia immer)' \\
\hline$(31 \mathrm{~g})$ & hamíime & /Ra'mi:me/ & 'sky' \\
\hline$(31 \mathrm{~h})$ & xasáacoj & 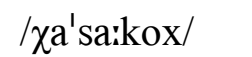 & 'sina (cactus) (Stenocereus alamosensis)' \\
\hline & \multicolumn{3}{|c|}{ Putatively monomorphemic words with four syllables (not common): } \\
\hline & tacazáca & /taka'saka/ & 'inchworm' \\
\hline (32b) & cascamáma & /kaska'mama/ & 'an unidentified stinkbug' \\
\hline$(32 \mathrm{c})$ & coziháamaj & /kofi'Ra:max/ & 'a small non-flying biting insect' \\
\hline
\end{tabular}

These examples suggest that the general rule in Seri is to construct a trochaic foot (a moraic trochee, as we see in section 6) at the right edge of the domain. Complications are discussed in the next two sections. The nature of the domain is discussed in section 8 .

\section{Quantity sensitivity and extrametricality}

The stress pattern is affected by the weight of a syllable. When the last syllable in the domain has a long vowel, a diphthong, or a complex coda, that syllable is stressed. However, as can be seen by examples in (22), (24), (26), (28), and (30) - and many more - the final consonant does not contribute to the syllable weight for this purpose (although we have already seen that a simple coda helps to meet the bimoraic requirement for the minimal word). Therefore I propose that the

\footnotetext{
${ }^{16}$ Note that (31e) has a long vowel plus short vowel in the nucleus and (31f) has a three-mora nucleus.

${ }^{17}$ This word has at least three major variants among modern-day speakers. The recording includes two of these: the

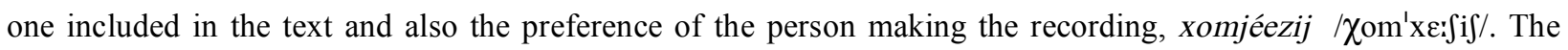
same person also pronounces the $m$ here more as a labial-velar (with clear closure of the lips) rather than the simple velar that is more commonly heard.
} 
final consonant is extrametrical (Hayes 1982, Hayes 1995). As a result, a final syllable with a simple coda is light for the purposes of foot construction.

(33) The final consonant of the domain is extrametrical (indicated here by angle brackets). Example: xa . má. ta $<\mathrm{j}>$ / $\chi$ a'matax/ 'broth'

The following examples show final stress due to a final heavy syllable.

The final syllable is heavy because it has a complex nucleus

Three-syllable words

(34a) hacosáa /Rako'sa:/ 'pole used to harvest sahuaro and sahueso fruit'

(34b) hacozquíif /Rako'Ski: $\phi /$ 'pole used to harvest pitaya agria cactus fruit'

(34c) ihatalháa /i2ata'43a:/ 'to buy' (infinitive)

(34d) patpayóo /patpa'jo:/ 'juvenile zebra-tailed lizard (Callisaurus draconoides)'

(34e) xomcahái / $\chi$ omka'?ai/ 'an unidentified small round flounder'

(34f) xomcahíift / $/$ omka'?i:фt/ 'oregano (Lippia palmeri)'

(34g) xomcahóij / $\chi 0 m k a '$ 'oix/ 'a cholla-like cactus (Grusonia reflexispina, G. marenae)'

Two-syllable words

(35a) comcáac /kom'ka:k/ 'Seri people'

(35b) conée /ko'ne:/ 'grass'

(35c) copsíij /ko'psi:x/ 'by-the-wind sailor (a hydrozoan, Porpita pacifica)'

(35d) matmíijc /ma'tmixk/ 'an unidentified species of moth'

(35e) maxáa /ma' $\chi$ a:/ 'sand snake (Chilomeniscus stramineus)'

(35f) najóo /na'xo:/ 'spotted sandbass (Paralabrax maculatofasciatus)'

(35g) nojcáasjc /no'xkaisxk/ 'American oystercatcher (Haematopus palliatus)'

(35h) pajíi /pa'xi:/ 'obsidian'

(35i) sahmées /sa?'me:s/ 'orange (fruit)'

(35j) tosnóom /to'sno:m/ 'bonefish (Albula spp.)'

(35k) xajii $\quad / \chi a ' x i: / \quad$ burrow (n.)'

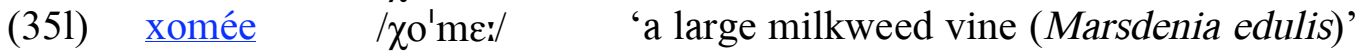

The final syllable is heavy because it has a non-extrametrical consonant in the coda Three-syllable words

(36a) hanzajíp $<j>\quad /$ Ranfa'xipx/ 'plate'

(36b) hasahcáp $<$ jö $>$ /Rasa?' $\mathrm{kapx}^{\mathrm{w}} /$ 'old man cactus (Lophocereus schottii)'

(36c) icocáx $<z>\quad /$ iko'kaxj/ 'gypsum'

Two-syllable words ${ }^{18}$

(37a) cacájö $<\mathrm{c}>\quad / \mathrm{ka}^{\prime} \mathrm{kax}^{\mathrm{w}} \mathrm{k} / \quad$ 'bagworm moth (Oiketicus sp.)'

(37b) conám $<j>\quad / k o$ 'namx/ 'a large unidentified grasshopper'

(37c) hamác $<j>\quad /$ la'makx/ 'cliff spurge (Euphorbia misera)'

(37d) moxhám $<\mathrm{t}>\quad / \mathrm{mo}^{\prime} \chi$ ?amt/ 'last year'

(37e) $\quad$ sapát $<x>\quad /$ sa'pat $\chi /$ 'sweetbush (Bebbia juncea)'

(37f) tacám $<\mathrm{n}>\quad /$ ta'kamn/ 'slipper lobster (Evibacus princeps)'

(37g) tajís $<1>\quad /$ ta'xist/ 'an unidentified species of fish'

(37h) $\quad$ xazép $<1>\quad / \chi a^{\prime} \int \varepsilon p 1 / \quad$ 'an unidentified species of porpoise or dolphin'

\footnotetext{
${ }^{18}$ The word hantpízl /Rantpifł/ 'long-nosed leopard lizard (Gambelia wislizenii)' was or should be in this list, but as one listening to the recordings will perceive, the stress pattern is not clearly Weak-Strong nor clearly Strong-Weak.
} 


\section{Exceptional extrametrical syllables}

Some nouns idiosyncratically have an extrametrical syllable as indicated below with angle brackets. ${ }^{19}$ It is not the normal case (unlike English, see Hayes 1982). Therefore a few nouns with three or more syllables have the accent on the penultimate syllable. An almost complete listing is given in (38).

\begin{tabular}{|c|c|c|c|}
\hline $\begin{array}{l}(38 \mathrm{a}) \\
(38 \mathrm{~b}) \\
(38 \mathrm{c}) \\
(38 \mathrm{~d})\end{array}$ & $\begin{array}{l}\text { cáamo }<\text { pxa }> \\
\text { catápo }<\text { ra }> \\
\text { cóto }<\text { taj }> \\
\text { cahíco }<\text { sa }>\end{array}$ & $\begin{array}{l}\text { /'ka:mop } \chi \text { a/ } \\
\text { /ka'tapora/ } \\
\text { /'kototax/ } \\
\text { /ka'?ikosa/ }\end{array}$ & $\begin{array}{l}\text { 'white-lined sphinx moth (Hyles lineata)' } \\
\text { 'robber fly (Asilidae)' } \\
\text { 'boojum tree (Fouquieria columnaris)' } \\
\text { 'variety of mule deer (Odocoileus hemionus) } \\
\text { without testicles, found only on Tiburon Island' }\end{array}$ \\
\hline (38e) & cahíixo $<$ na $>$ & 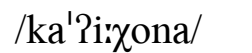 & 'limpet (Acmaeidae, Calyptraeidae)' \\
\hline & háaca & /'Ra:ka & nesquite po \\
\hline & & & \\
\hline & $0<$ toi $>$ & /'Rasotox/ & \\
\hline & Hatáama $<$ ti $>$ & /Ra'ta:mati/ & \\
\hline & héme & /'?emexa/ & at (?) (Neotoma lepida (?))' \\
\hline & & /'Re:Sitim/ & \\
\hline & & /Ro'napota/ & (place name) \\
\hline & satóma $<$ tox $>$ & /sa'tomato / & 'mesquite driftwood' \\
\hline & $a<$ jam $>$ & /'so:kaxam/ & \\
\hline & ahíco < sa > & /xa'?ikosa/ & 'a rock shell (Haustellum elenensis)' \\
\hline
\end{tabular}

A few of these examples - (38a) for example - might be explained without extrametricality by suggesting that stress may occur even farther to the left because of a long vowel in the nucleus. However, such an attempt would still leave the examples without long vowels unexplained.

\section{Stress domain: the root}

The presentation so far has purposefully focused on words without affixes. With more data it can be seen clearly that the domain of stress placement is the root. Stress does not fall on a possessor prefix or any verb prefix, for example, except in the cases of fusion mentioned in section 2). The following data illustrate this fact. In possessed forms without suffixes the stress occurs on the final syllable (the root) rather than on the first syllable (the prefix) even though these words have the same type of CV pattern that was illustrated in (22).

\begin{tabular}{|c|c|c|c|c|}
\hline & & /2i''lit/ & 1Possessor-head & 'my head' \\
\hline & xâp & /i'xap/ & 3Possessor-gizzard & 'its gizzard' \\
\hline & $\frac{\text { hi-mác }}{\text { j-háx }}$ & /Ri'mak/ & $\begin{array}{l}\text { 1Possessor-sponsor } \\
\text { 3Possessor-fat }\end{array}$ & $\begin{array}{l}\text { 'my sponsor' } \\
\text { 'its/her/his fa }\end{array}$ \\
\hline
\end{tabular}

Similarly, suffixes are not in the domain of stress, even when they have two syllables (not a common situation for nouns). ${ }^{20}$ The final consonant of the root might be extrametrical in these

\footnotetext{
${ }^{19}$ Of course, an alternative analysis is that these are simply cases of lexical accent.

${ }^{20}$ The marking of pluralization on verbs and nouns is among the most complicated aspects of Seri noun and verb morphology (Moser 1961 and chapter 4 of Marlett 1981). Given the severe amount of complication, fusion, and irregularity, there is no doubt that they are actual suffixes rather than clitics. Examples of two-syllables after the root
} 
cases as well. Abundant and convincing data to determine this are not easily obtained, but the available data are consistent with this claim. If the $l$ (a lateral fricative) were not extrametrical in (40b), the last syllable of the root would be heavy and should attract stress. If the lateral fricative is extrametrical, the placement of stress is exactly as expected. (There are two ways around this: first, claim that the $l$ is part of the suffix, although this does not appear to be true; second, claim that the $l$ is syllabified in the onset of the syllable $c a$.)

\begin{tabular}{|c|c|c|c|c|}
\hline (40a) & $\begin{array}{l}\text { hóopa }<\text { t }>\text { - } \\
\text { alca }\end{array}$ & /'Po:patałka/ & $\begin{array}{l}\text { wave-Plural } \\
\text { (singular: hóopati: see }(43 \mathrm{c}) \text { ) }\end{array}$ & 'waves' \\
\hline$(40 b)$ & $\overline{\underline{1} \text { sta }}<1>$-ca & /'istałka/ & $\begin{array}{l}\text { leaf-Plural } \\
\text { (singular: ísti) }\end{array}$ & 'leaves' \\
\hline$(40 c)$ & háaho-lcam & /'Ra:Rołkam/ & $\begin{array}{l}\text { road-Plural } \\
\text { (singular: háaho) }\end{array}$ & 'roads' \\
\hline (40d) & tacazáca-taj & /taka'Jakatax/ & $\begin{array}{l}\text { inchworm-Plural } \\
\text { (singular: tacazáca) }\end{array}$ & 'inchworms' \\
\hline
\end{tabular}

I do not present verb data here, but they are exactly parallel to what has been shown for nouns although there are many more prefixes that occur on verbs than on nouns. ${ }^{21}$

\section{Outstanding exceptions}

In spite of all of the factors presented so far that may be used to account for regular stress placement - domain, extrametrical consonants, sensitivity to weight - and the device of lexically marking some extrametrical syllables, some few exceptions still occur and defy explanation. The existence of such words may suggest that lexical accent is necessary (and thus make the idiosyncratic extrametrical syllables unnecessary). First, some words stress a final light syllable. These words include (but are not limited to) the following: ${ }^{22}$

\begin{tabular}{|c|c|c|c|}
\hline (41a) & hamác & /Ra'mak/ & 'fire' \\
\hline$(41 b)$ & coláxö & $/ \mathrm{ko}^{\prime}+\mathrm{a} \chi^{\mathrm{w}} /$ & 'goliath grouper (Epinephelus itajara)' \\
\hline (41c) & hamíp & /Ra'mip/ & 'spiderling (Boerhavia coulteri)' \\
\hline$(41 d)$ & haznám & $/ 2 a^{\prime} \int n a m /$ & 'very large variety of totoaba (Totoaba macdonaldi)' \\
\hline$(41 \mathrm{e})$ & imozít & /imo'sit/ & 'its half' \\
\hline$(41 \mathrm{f})$ & joját & /xo'xat/ & 'saya (Amoreuxia palmatifida)' \\
\hline (41g) & najmís & /na'xmis/ & 'a desert phacelia (Phacelia ambigua)' \\
\hline$(41 \mathrm{~h})$ & otác & /o'tak/ & 'toad, frog' \\
\hline (41i) & saxáp & /sa' $\chi a p /$ & 'a bittersweet clam (Glycymeris gigantea)' \\
\hline$(41 \mathrm{j})$ & xojmás & / $0^{\prime} \mathrm{xmas} /$ & 'an unidentified land snail' \\
\hline$(41 \mathrm{k})$ & acacám & /aka'kam/ & 'his/her son-in-law' \\
\hline
\end{tabular}

are not hard to find with verbs, such as itjaxajam /i'txaxaxam/ ('did they inhale it repeatedly?'), which contains the root $\{\mathrm{xa} \chi\}$. More examples are given in (44).

${ }^{21}$ Out of the hundreds of verbs in the Seri dictionary, eight roots are unusual in that they obligatorily require the stress to precede the root, using epenthetic vowels when necessary to receive the stress (see chapter 5 of Marlett 1981).

${ }^{22}$ There is no evidence that a final vowel has been lost in any of these words except for words with labialized consonants; the latter have transparently arisen in Seri through the loss of an unstressed $o$. 
With final open syllable

$$
\text { coqué }^{23} \quad / \mathrm{ko}^{\mathrm{l}} \mathrm{ke} / \quad \text { 'chili' }
$$

Furthermore, some words have stress on the penultimate syllable even when the final syllable is heavy due to two final consonants.
$\underline{\text { xnícatl }}$
/'xnikatł/
hápats
/'Papats/
'Colorado snapper (Lutjanus colorado)'
hóopatj
/'Po:patx/
'Apache'
xpanómalc
/xpa'nomałk/
tajísipl
/ta'xisipł/
'wave' (n.)
tojquítajc
/to'xkitaxk/
'octopus' (in coyote's speech)
(43h)
xpaléemelc
/xpa'le:mełk/
'Panamic sergeant major (Abudefduf troschelii)'
'great horned owl (Bubo virginiana)'
xpasíiticl / / pa'si:tikt/
'olive shell (Olividae) and cone shell (Conidae)'
(43i)
yasámict
/ja'samikt/
'Harris' antelope squirrel (Ammospermophilus harrisii)'
zicázijc $^{24}$
/ Si'kaSixk/
'its tail (of black sea turtle)'
'red-billed tropicbird (Phaethon aethereus)'

The word coxixám 'watermelon' also is an exception, but its etymology is clear; it comes from cóoxi 'dead one (especially animal)' i-xám '3Possessor-squash' (although I don't know the story behind this one), which shows the evolution of a phrase with regular stress on each word leading to a compound with final - and irregular - stress. Some of the words listed here may also be explained by a similar historical development. The word najmis, for example, surely is a word composed historically of [...]naj cmis 'what resembles [...]naj' ${ }^{25}$ However, the full content of the word that ended in the syllable naj is not known.

Verbs also demonstrate roots that are similarly exceptional. Some examples with root-initial stress are Vatajc 'vomit' (which figures in the etymology of tojquítajc 'great horned owl' in (43e)), Vacatx 'abandon', Vemetx (the verbal element in the expression iiqui vemetx 'twist (like screw)'), Vixepxat 'stink' (archaic), Vesijc 'probe for a thorn', and Viimapxij 'iridescent with dark colors'. See also Vihéezilc 'thin due to sickness' with stress on the second syllable of the root. The final heavy syllables are irrelevant in these cases.

The discussion so far has omitted important complications that are found in the derivation of plural forms of the verbs. ${ }^{26}$ Verbs commonly have four different stems relating to number, as illustrated by the following partial paradigms of the verbs $\sqrt{a x p x}$ 'be angry with, scold (someone)', Vatólec 'ask for help from (someone)', $\sqrt{ }$ acösj 'shake (something)', $\sqrt{ }$ panzx 'run', and Vatáaca 'send (something)'. The verbs are cited here in the dependent realis form which permits one to clearly separate the prefixes.

\footnotetext{
${ }^{23}$ Some speakers seem to actually pronounce this word as coquée, the way it was recorded by Edward Moser in earlier fieldwork. One reliable consultant, however, insists that it is a short final vowel, although some others disagree.

${ }^{24}$ This word has a possible etymology that includes the word zíic/'Si:k/ 'bird' plus a modifer.

${ }^{25}$ This was suggested to me long ago by Becky Moser.

${ }^{26}$ These forms were a major focus of Moser (1961) and also chapter 4 of Marlett (1981). 


\begin{tabular}{|c|c|c|c|c|}
\hline & \multicolumn{2}{|c|}{ Singular Subject } & \multicolumn{2}{|l|}{ Plural Subject } \\
\hline & Stem 1 & Stem 2 & Stem 3 & Stem 4 \\
\hline & Simple & Imperfective & Simple & Imperfective \\
\hline$(44 a)$ & i-t-áxpx & i-t-áxapx-im & i-t-áxapx-at & i-t-áxapx-olca \\
\hline & $/ i^{\prime} \operatorname{ta} \chi p \chi /$ & 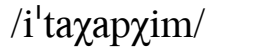 & /i'taxapxat/ & 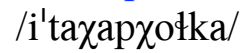 \\
\hline$(44 b)$ & i-t-ácösj & i-t-ácosl & i-t-ácösl-coj & i-t-ácosl-am \\
\hline & $/ \mathrm{i}^{1} \operatorname{tak}^{\mathrm{w}} \mathrm{Sx} /$ & /i'takost/ & /i'tak ${ }^{\mathrm{w}}$ słkox/ & /i'takosłam/ \\
\hline$(44 c)$ & $\underline{\text { i-t-atólec }}$ & i-t-atólejqu-im & i-t-atólej-oj & i-t-atólejc-am \\
\hline & /ita'tołek/ & /ita'tołexkim/ & /ita'tołexox/ & /ita'tołexkam/ \\
\hline$(44 d)$ & t-pánzx & t-pánozx-im & t-páncojc & t-páncox-lca \\
\hline & $/ \operatorname{tpan} \int \chi /$ & 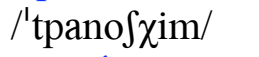 & /'tpankoxk/ & 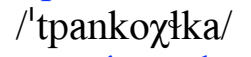 \\
\hline$(44 \mathrm{e})$ & i-t-atáaca & i-t-atáaca-tim & i-t-atáac-joj & i-t-atáac-tolca \\
\hline & /ita'ta:ka/ & /ita'ta:katim/ & /ita'ta:kxox/ & /ita'ta:ktołka/ \\
\hline
\end{tabular}

If in fact the stress rule has the root as its domain, one must know where the root begins and ends in each case. The roots of the verbs in (44) are quite obvious - at least for the purposes of stress-placement - although the post-tonic vowel is lost in stem 1 of (44a), stems 1 and 3 of (44b) (at the same time changing $c / \mathrm{k} /$ to $c \ddot{o} / \mathrm{k}^{\mathrm{w}} /$ ), stems 1,3 and 4 of (44d), and stems 3 and 4 of (44e). But note that stress does not move around in these roots even though the final syllable of the root is heavy in some of the forms. However this is to be accounted for, in no verb in the language does stress move around due to changes in the syllable structure. ${ }^{27}$ Verbs are also more exceptional in ignoring the moras of consonants, as the examples in (44) show. A complex nucleus in the root, on the other hand, never fails to attract stress.

\section{Conclusion}

This paper has presented to English readers two new proposals for Seri. The first is that a minimal word condition exists in the language; a word must have at least two moras. The final consonant contributes a mora for this condition. The second is that stress placement is based on the construction of a moraic trochee at the right edge of the root. The final consonant of the root does not contribute a mora for this purpose; it is extrametrical. The final syllable is heavy only if it has two or more vowels in the nucleus and/or two or more consonants in the coda. Some roots have extrametrical final syllables although this is not the predominate pattern in any word class. Finally, some exceptional words - some nouns, but especially verbs - continue to defy inclusion into the general account.

\section{References}

Campbell, Lyle. 1997. American Indian languages: The historical linguistics of Native America. Oxford and New York: Oxford University Press.

Hayes, Bruce. 1982. Extrametricality and English stress. Linguistic Inquiry 13:227-76.

Hayes, Bruce. 1995. Metrical stress theory: principles and case studies. Chicago: University of Chicago.

Kroeber, A. L. 1931. The Seri. Southwest Museum Papers 6. Los Angeles: Southwest Museum.

\footnotetext{
${ }^{27}$ The only situation which might be construed this way is when the infix -too- appears in plural forms. Compare singular stem Vaas 'deflate' with its plural stem Vatóosi; and Victim 'cross (something)' with its plural stem Vitóocl, for example.
} 
Marlett, Stephen A. 1981. The structure of Seri. Doctoral dissertation. University of California, San Diego.

Marlett, Stephen A. 1988. The syllable structure of Seri. International Journal of American Linguistics 54:245-78.

Marlett, Stephen A. 2002. Reanalysis of passive and negative prefixes in Seri. Linguistic Discovery 1.1. [http://linguistic-discovery.dartmouth.edu/WebObjects/Linguistics.woa/1/ page/article/1]

Marlett, Stephen A. 2005. A typological overview of the Seri language. Linguistic Discovery 3.1:54-73. [http://journals.dartmouth.edu/cgi-bin/WebObjects/Journals.woa/2/ xmlpage/1/article/282]

Marlett, Stephen A. 2006a. Acento, extrametricalidad y la palabra mínima en seri. Encuentro de lenguas indígenas americanas: Libro de actas. Santa Rosa de La Pampa, Argentina: Universidad Nacional de La Pampa.

Marlett, Stephen A. 2006b. La evolución del alfabeto seri. Octavo Encuentro Internacional de Lingüística en el Noroeste, vol. 3:311-329. Hermosillo: Universidad de Sonora.

Marlett, Stephen A. 2008. The Seri-Salinan connection revisited. International Journal of American Linguistics 74.3:393-99.

Marlett, Stephen A.; F. Xavier Moreno Herrera; and Genaro G. Herrera Astorga. 2005. Seri. Journal of the International Phonetic Association 35.1:117-121.

Moser, Edward W. 1961. Number in Seri verbs. M.A. thesis, University of Pennsylvania.

Moser, Edward W. and Mary B. Moser. 1965. Consonant-vowel balance in Seri (Hokan) syllables. Linguistics 16:50-67.

Moser, Mary B. and Stephen A. Marlett, compilers. 2005. Comcáac quih yaza quih hant ihíip hac: Diccionario seri- español-inglés. México, D.F. y Hermosillo: Plaza y Valdés Editores and Universidad de Sonora. Available on-line: [http://lengamer.org/admin/language_folders/seri/user_uploaded files/links/File/Diccionario Seri2005.pdf]

Author's contact information:

Stephen Marlett

63955 E. Condalia

Tucson, AZ 85739

E-mail: steve_marlett@sil.org 